\title{
Optimization of the HS-SPME-GC/MS technique for the analysis of volatile compounds in caprine Coalho cheese using response surface methodology
}

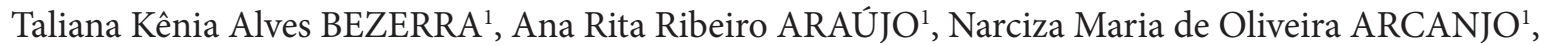
Flávio Luís Honorato da SILVA ${ }^{1}$, Rita de Cássia Ramos do Egypto QUEIROGA ${ }^{1}$, Marta Suely MADRUGA ${ }^{1 *}$

\begin{abstract}
Caprine Coalho cheese presents great potential for a typical protected designation of origin, considering that this traditional Brazilian cheese presents a slightly salty and acid flavor, combined with a unique texture. This study optimized the HS-SPME-GC-MS methodology for volatile analysis of Coalho cheese, which can be used as a tool to help in the identification of the distinctive aroma profile of this cheese. The conditions of equilibrium time, extraction temperature and time were optimized using the statistical tool factorial experimental design $2^{3}$, and applying the desirability function. After the evaluation, it was concluded that the optimum extraction conditions comprised equilibrium and extraction time of 20 and 40 minutes, respectively; and ideal extraction temperature of $45^{\circ} \mathrm{C}$. The optimum extraction of volatile compounds in goat Coalho cheese captured 32 volatile compounds: 5 alcohols, 5 esters, 3 ketones, 6 acids, 3 aldehydes, 3 terpenes, and 7 hydrocarbons.
\end{abstract}

Keywords: dairy products; cheese; aromas; GC/MS.

Practical Application: Application of factorial design to optimize the extraction conditions of volatile compounds in caprine Coalho cheese.

\section{Introduction}

Caprine cheese is a product consumed worldwide, due to the growing demand for goat dairy products. Coalho cheese is a traditional, partially-cooked or cooked curd cheese which has been traditionally produced and consumed in Northeastern Brazil for over 150 years (Queiroga et al., 2013).

Caprine Coalho cheese is a very sought after product thanks to its slightly salty and acid flavour, alongside its "rubberized" texture. This unique texture is the result of its resistance to heat, which prevents it from melting when cooked. This allows the preparation of the popular "roasted Coalho cheese", with its own distinctive volatile profile (Silva et al., 2012). In addition, caprine Coalho cheese is a product of great commercial value for a number of reasons: its simple low-cost production process, the high process yield, its low allergenic potential and high digestibility, as well as its excellent nutritional value (Oliveira et al., 2012; Santos et al., 2012).

On the other hand, caprine Coalho cheese presents great potential for a typical protected designation of origin (PDO), since the PDO label implies that the product has distinctive characteristics that are connected to traditional production methods. The PDO could be used as a tool of the to contribute to the economical sustainability of the Northeast region, especially the rural areas. It must be mentioned that even though it has been produced for over one century, Coalho cheese is still manufactured using non-standardized processes, which causes variability mainly in sensory properties (Queiroga et al., 2013), and consequently in its aroma profile.

It is well known that the volatile profile is very important for the organoleptic quality of cheeses. It can be considered a finger print since the flavour of a cheese variety is the result of a specific balance between the volatile compounds produced during the manufacture process. According to Delgado et al. (2011), the basic flavor of any cheese is formed by the complex balance involving non-volatile and volatile substances from the microbiological and biochemical activities, which range from the raw material, the process and maturation. The volatile compounds are among the most important criteria of cheese quality for consumer acceptance. These compounds comprise the flavor characteristic of the same (González-Martín et al., 2014).

Gas chromatography coupled to mass spectrometry (GC-MS) has been extensively employed to identify and quantify aroma/flavor components in several types of foodstuffs, including cheeses. Traditional extraction methods for cheese volatiles, such as steam or vacuum distillation, are hardly used anymore (Moio \& Addeo, 1998; Vandeweghe \& Reineccius, 1990), mainly due to their poor recovery rate of highly volatile compounds and the disappearance of thermally sensitive compounds associated with the formation of artifacts (Condurso et al., 2008).

Headspace solid phase micro-extraction (HS-SPME) is a technique currently used for a great variety of cheeses, as it 
provides many advantages: it is an easy-to-use, relatively fast and sufficiently sensitive technique which does not require organic solvents. The results obtained with this technique are very promising and a considerable number of compounds have already been described in a great variety of cheeses (Pinho et al., 2003; Mallia et al., 2005; Condurso et al., 2008; Januszkiewicz et al., 2008); however, information regarding the volatile fraction and the use of SPME extraction of volatiles from caprine Coalho cheese (known to have a unique sensory profile) is not yet present in literature.

In order to have capture of volatile compounds by the fibre sample analyzed is allocated in a tightly closed glass bottle and subjected to a given temperature until the formation of the headspace to occur during equilibration. After the fibre is exposed to the headspace for desorption to occur during a certain time of extraction (Delgado et al., 2011).

The extraction parameters equilibrium time, extraction time and extraction temperature should be tested so as to obtain the optimum conditions for that permits the capture of a greater amount of the compounds, since these factors are the most frequently reported in the literature as factors that influence the performance of the analysis (Ma et al., 2013).

Having said that, this study, through the use of response surface methodology (RSM), aimed to develop and optimize the Solid Phase Micro Extraction technique (SPME), so that it may be used to characterize the volatile fraction of Coalho cheese. The optimization of HS-SPME-GC/MS methodology could be used as a tool to help the identification of the distinctive aroma profile of Coalho cheese, and will be used in further studies on the aroma profile of raw and cooked caprine Coalho cheese.

\section{Materials and methods}

\subsection{Standards}

The homologous series of n-alkanes C8 - C25, used for calculating the linear retention index of volatiles, was supplied by Fluka (Sigma Aldrich Chemie GmbH, Steinheim, Germany).

\subsection{Extraction of Coalho cheese volatile compounds by HS-SPME}

Samples were prepared by weighing $20 \mathrm{~g}$ of grated Coalho cheese in $60 \mathrm{~mL}$ vials sealed with a polytetrafluoroethylene silicone septum (Supelco, Bellenfont, PA, USA). The system was submitted to an extraction temperature (T) of 20,30, 45, 60, and $70{ }^{\circ} \mathrm{C}$ in a water bath and an equilibrium time (Eq) of $3,10,20$, 30 , and 37 minutes before fibre exposure. Prior to extractions, the fibre was conditioned to the gas chromatograph injector at the temperature of $270{ }^{\circ} \mathrm{C}$ for 60 minutes. Afterwards, the SPME fibre was exposed to the headspace, above the Coalho cheese sample for an extraction time (Ex), of 6, 20, 40, 60, and 74 minutes. Then the fibre was retracted into the needle and transferred to the gas chromatograph injector where analytes were desorbed. The values tested were all obtained from previous studies, in which they had yielded satisfactory results for SPME extraction in cheeses (Delgado et al., 2010; Hayaloglu et al., 2013; Kondyli et al., 2013).
Prior to the optimization of the SPME conditions for the analysis of volatile components, a screening was performed to select the appropriate fibre. Fibres were purchased from Supelco (Bellofonte, PA, USA). Four fibres were tested and compared: divinylbenzene/Carboxen/polydimethylsiloxane (DVB/CAR/PDMS) 50/30 $\mu \mathrm{m}$; polydimethylsiloxane (PDMS) $100 \mu \mathrm{m}$; Carbowax/divinylbenzene (CW/DVB) $65 \mu \mathrm{m}$ and polydimethylsiloxane/divinylbenzene (PDMS/DVB), $65 \mu \mathrm{m}$. Before extraction began, each extraction fibre was conditioned according to the manufacturer's prescription.

Of the four fibres evaluated, the divinilbenzeno/Carboxen/ polidimetilsiloxano 50/30 $\mu \mathrm{m}$ (DVB/CAR/PDMS) fibre presented the best performance, with a higher number of volatiles in the cheese samples, and was therefore selected to be used in the HS-SPME volatiles analysis in Coalho cheese.

\subsection{Optimal conditions for the extraction of Coalho cheese volatiles}

To optimize extraction by HS-SPME, a central composite rotational design (CCRD) was used, in which three independent variables were analyzed: equilibrium time (Eq), extraction time (Ex) and extraction temperature (T): The design included seventeen trials which comprised eight factorial points, six axial points and three replicates of the central point for knowing the experimental error associated with measurements. The response surface model was elaborated using the following Equation 1:

$\mathrm{y}=\beta 0+\beta 1 \mathrm{Eq}+\beta 2 \mathrm{Ex}+\beta 3 \mathrm{~T}+\beta 4 \mathrm{Eq}^{2}+\beta 5 \mathrm{Ex}^{2}+$

$\beta 6 \mathrm{~T}^{2}+\beta 7 \mathrm{Eq} . \mathrm{Ex}+\beta 8 \mathrm{Eq} . \mathrm{T}+\beta 9 \mathrm{Ex} . \mathrm{T}$

Where $y$ is the response value predicted by the model; $\beta_{0}$ is the mean coefficient (or the constant) $\beta 1, \beta 2$ and $\beta 3$ are the linear, $\beta 4, \beta 5$ and $\beta 6$ the quadratic and $\beta 7, \beta 8$ and $\beta 9$ the interaction coefficients. In this model Ex (extraction time), $\mathrm{Eq}$ (equilibrium time) and $\mathrm{T}$ (extraction temperature) are the independent variables. The dependent variable in this study is the number of peaks in the chromatograms.

\subsection{Statistical analysis}

The response function (y) was used to perform regression analyses and analyses of variance (ANOVA) for the regression. The equation model was fitted to experimental data to yield the proposed model. Response surface graph and desirability parameters were generated for the response function (y), i.e. total number of peaks. The executed analyses, desirability and response surface were performed with STATISTICA 8.0 software (StatSoft Inc., 2007). After response surface analysis and graphing of the desirability for the maximum number of volatiles extracted, the proposed model was validated by performing new assays in triplicate. The results were compared with the estimated response (y) by Student's t-test $(\mathrm{p}<0.05)$.

\subsection{Gas chromatography-mass spectrometry conditions}

For separation and identification of compounds extracted from Coalho cheese, a Varian 3800 gas chromatograph coupled to a Varian Saturn 2000R mass detector (Varian Inc., Palo Alto, 
California) and VF-5 ms column $(60 \mathrm{~m} \times 0.25 \mathrm{~mm} \times 0.25 \mu \mathrm{m})$ was used (Agilent, Santa Clara, California).

The temperature programming of the gas chromatograph oven started at $40{ }^{\circ} \mathrm{C}$ for 10 minutes, followed by a $5{ }^{\circ} \mathrm{C} / \mathrm{min}$ ramp increase up to $240{ }^{\circ} \mathrm{C}$, maintaining this temperature for 11 minutes, with a total running time of 61 minutes. This temperature programming was proposed after preliminary tests. The injector used was the split type with manual injection, maintained at a temperature of $250^{\circ} \mathrm{C}$. Helium was used as carrier gas at a constant flow rate of $1.0 \mathrm{~mL} / \mathrm{min}$.

The mass spectrometer was operated by electron impact at a source temperature of $200{ }^{\circ} \mathrm{C}$ and a ionization energy of $70 \mathrm{eV}$ and a scan range from m/z 29 to $\mathrm{m} / \mathrm{z} 400$ at $3.33 \mathrm{scan} / \mathrm{s}$. The identification of volatile compounds was based on the comparison of their mass spectra with those of compounds previously analyzed, with NIST/EPA/NIH Mass Spectral Database (Version 2008), or spectra published in journals. To confirm the identity of each component, the linear retention index (LRI) was calculated using the retention times of a homologous series of n-alkanes C8-C25 and also by comparing the LRI of authentic compounds analyzed under similar conditions (Atasoy et al., 2013; Hayaloglu et al., 2013; Madruga et al., 2013).

\section{Results and discussion}

\subsection{Optimization of SPME parameters for volatiles in caprine Coalho cheese using response surface}

The experimental results of the CCRD shown in Table 1 and in the Pareto chart (Figure 1) expose the importance of the variables analyzed and their interactions. The number of peaks is a very important variable for determining the optimization parameters of chromatographic analysis, the greater the amount of detected peaks, the greater the quantity of compounds trapped by the fiber and detected by gas chromatography.
The resulting $\mathrm{R}^{2}$ in the model was 0.88421 , and, according to the $\mathrm{F}$ test, this was a significant regression, bearing in mind that the $\mathrm{F}_{\text {calculated }}>\mathrm{F}_{\text {tabled }}$ and showed no lack of fit $\left(\mathrm{F}_{\text {calculated }}<\mathrm{F}_{\text {tabled }}\right)$. Therefore, the Equation 2 for the dependent variable number of peaks was obtained.

$y=26.47+1.69(E x)+2.20(T)-1.29\left(E^{2}\right)-2.88\left(T^{2}\right)-2.13(E q . E x)$

Where $\mathrm{y}$ is the response value predicted by the model. In this model, Ex (Extraction Time), Eq (Equilibrium Time) and $\mathrm{T}$ (Extraction Temperature) are the independent variables. The dependent variable in this study is the number of peaks in the chromatograms.

After analyzing the data, a response surface (Figure 2) was obtained with the purpose of finding the optimal region and thus verify which independent variable values produced the best response.

From the Pareto Chart (Figure 1), it can be observed that equilibrium time and the interactions between 1 and 3 , and between 2 and 3 were not significant. Therefore, when creating the response surface, equilibrium time was fixed at the center point (20 minutes).

Based on the response surface (Figure 2), it can be observed that the region with the best response values is located between the marks of 40 minutes and 74 minutes of extraction time (Ex), and between the temperatures (T) of $38^{\circ} \mathrm{C}$ and $70{ }^{\circ} \mathrm{C}$. However, it is in the central region of the surface, where the central points of extraction time and temperature can be found, that the maximum response value can be seen.

According to Pérez-Palacios et al. (2012), an increase in extraction temperature leads to the release of a greater quantity of volatile compounds into the headspace, since the rise in temperature is proportional to the increase in the analyte

Table 1. Central composite rotatable design $\left(2^{3}\right)$ with the independent variables, levels and experimental responses $(\mathrm{Y}=$ number of peaks) of the SPME extraction of volatiles in coalho cheese.

\begin{tabular}{|c|c|c|c|c|}
\hline \multirow[b]{2}{*}{ Assay } & \multicolumn{3}{|c|}{ Independent Variables } & \multirow{2}{*}{$\begin{array}{l}\text { Response function } \\
\text { Number of Peaks }\end{array}$} \\
\hline & $\begin{array}{c}\text { Equilibrium Time } \\
\text { (minutes) }^{*}\end{array}$ & $\begin{array}{c}\text { Extraction Time } \\
(\text { minutes })^{*}\end{array}$ & $\begin{array}{c}\text { Extraction Temperature } \\
\left({ }^{\circ} \mathrm{C}\right)^{*}\end{array}$ & \\
\hline 1 & $-(10)$ & $-(20)$ & $-(30)$ & 16 \\
\hline 2 & $+(30)$ & $-(20)$ & $-(30)$ & 20 \\
\hline 3 & $-(10)$ & $+(60)$ & $-(30)$ & 24 \\
\hline 4 & $+(30)$ & $+(60)$ & $-(30)$ & 19 \\
\hline 5 & $-(10)$ & $-(20)$ & $+(60)$ & 23 \\
\hline 6 & $+(30)$ & $-(20)$ & $+(60)$ & 26 \\
\hline 7 & $-(10)$ & $+(60)$ & $+(60)$ & 30 \\
\hline 8 & $+(30)$ & $+(60)$ & $+(60)$ & 25 \\
\hline 9 & $-\alpha(3)$ & $0(40)$ & $0(45)$ & 24 \\
\hline 10 & $+\alpha(37)$ & $0(40)$ & $0(45)$ & 26 \\
\hline 11 & $0(20)$ & $-\alpha(6)$ & $0(45)$ & 19 \\
\hline 12 & $0(20)$ & $+\alpha(74)$ & $0(45)$ & 25 \\
\hline 13 & $0(20)$ & $0(40)$ & $-\alpha(20)$ & 16 \\
\hline 14 & $0(20)$ & $0(40)$ & $+\alpha(70)$ & 19 \\
\hline 15 & $0(20)$ & $0(40)$ & $0(45)$ & 29 \\
\hline 16 & $0(20)$ & $0(40)$ & $0(45)$ & 30 \\
\hline 17 & $0(20)$ & $0(40)$ & $0(45)$ & 28 \\
\hline
\end{tabular}

${ }^{\star}$ Coded independent variables and real. 


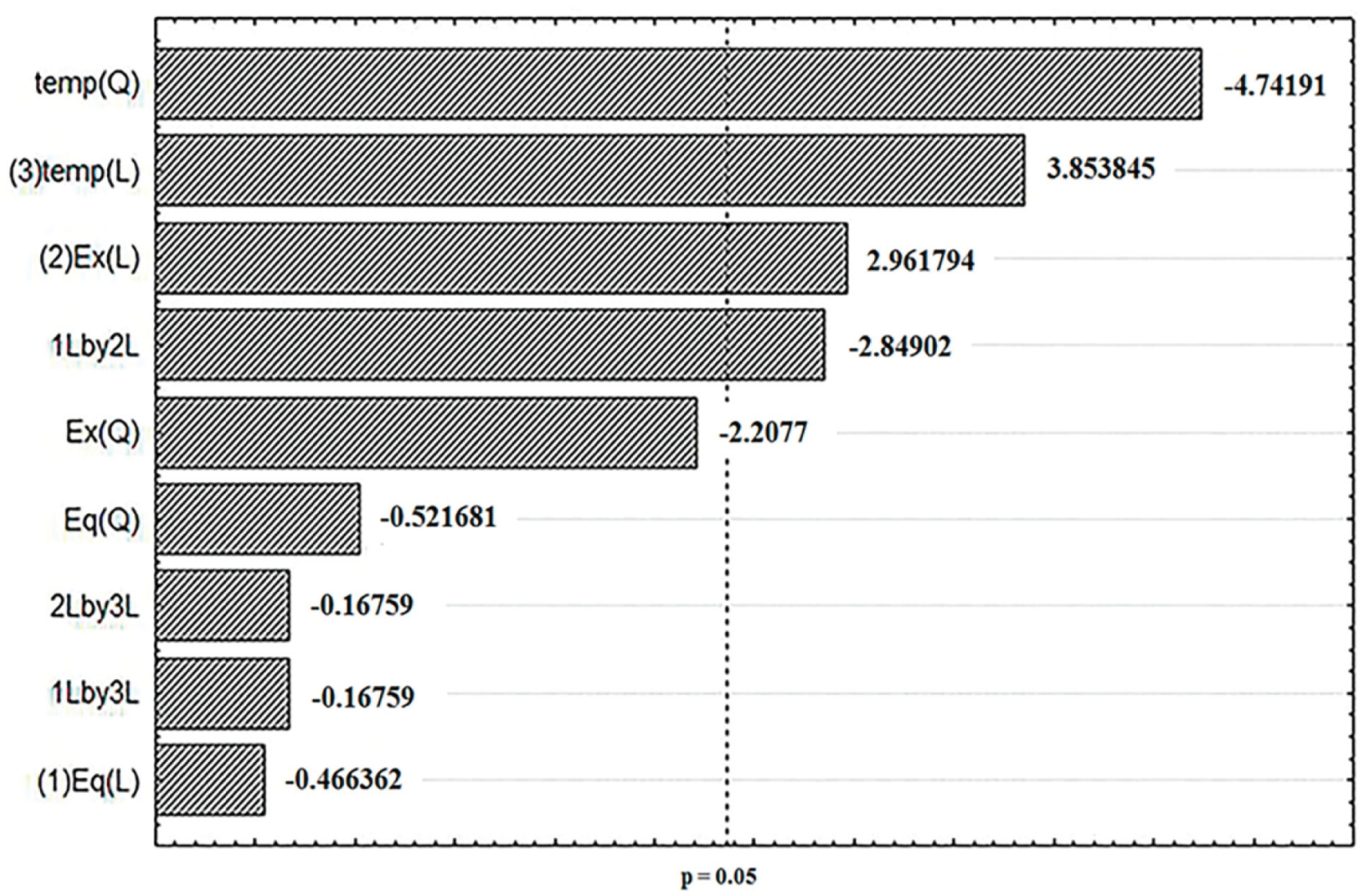

Figure 1. Pareto graphic of the dependent variable 'number of peaks'. ${ }^{\star}$ temp(Q): Extraction Temperature - Quadratic; temp(L): Extraction Temperature - Linear; Ex(L): Extraction Time - Linear; 1Lby2L: interaction between the parameters Equilibrium Time (Linear) and Extraction Time (Linear); $\operatorname{Ex}(\mathrm{Q})$ : Extraction Time - Quadratic; Eq(Q): Equilibrium Time - Quadratic; 2Lby3L: interaction between the parameters Extraction Time (Linear) and Extraction Temperature (Linear); 1Lby3L: interaction between the parameters Equilibrium Time (Linear) and Extraction Temperature (Linear); Eq(L); Equilibrium Time - Linear.

diffusion coefficient. However, high temperatures can also lead to the formation of aromatic compounds derived from the Maillard reaction or from caramelization. It may also provoke the degradation of some of the compounds from the product.

Longer exposure of the fiber to the headspace enables greater capture of the compounds until polymer saturation. Therefore, it is usually necessary to have longer extraction times during analysis, before balance between the headspace and the fiber polymer is reached (Barros et al., 2012; Trujillo-Rodríguez et al., 2014).

\subsection{Desirability parameter}

Figure 3 shows that the optimal parameters of this study were located in the exact region of the center point. The desirability parameter indicates the optimal region, taking into account all the variables, at the same time. The optimization desirability value was 0.74793 , which is considered a good, acceptable value, according to the values reported by Akhanazarova \& Kafarov (1982).

Trujillo-Rodríguez et al. (2014), who studied the type of polymer used in extraction via SPME, reported that the

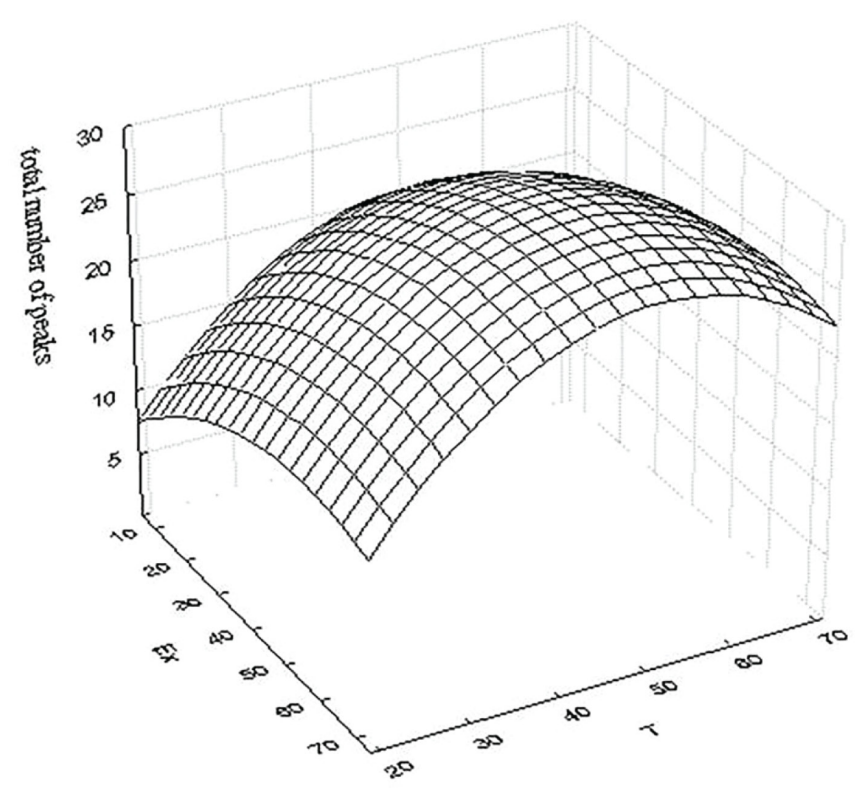

Figure 2. Response Surface for the dependent variable 'number of peaks'. Equilibrium time (Eq) was fixed at the center point. Ex (Extraction Time) and $\mathrm{T}$ (Extraction Temperature). 
Profiles for Predicted Values and Desirability
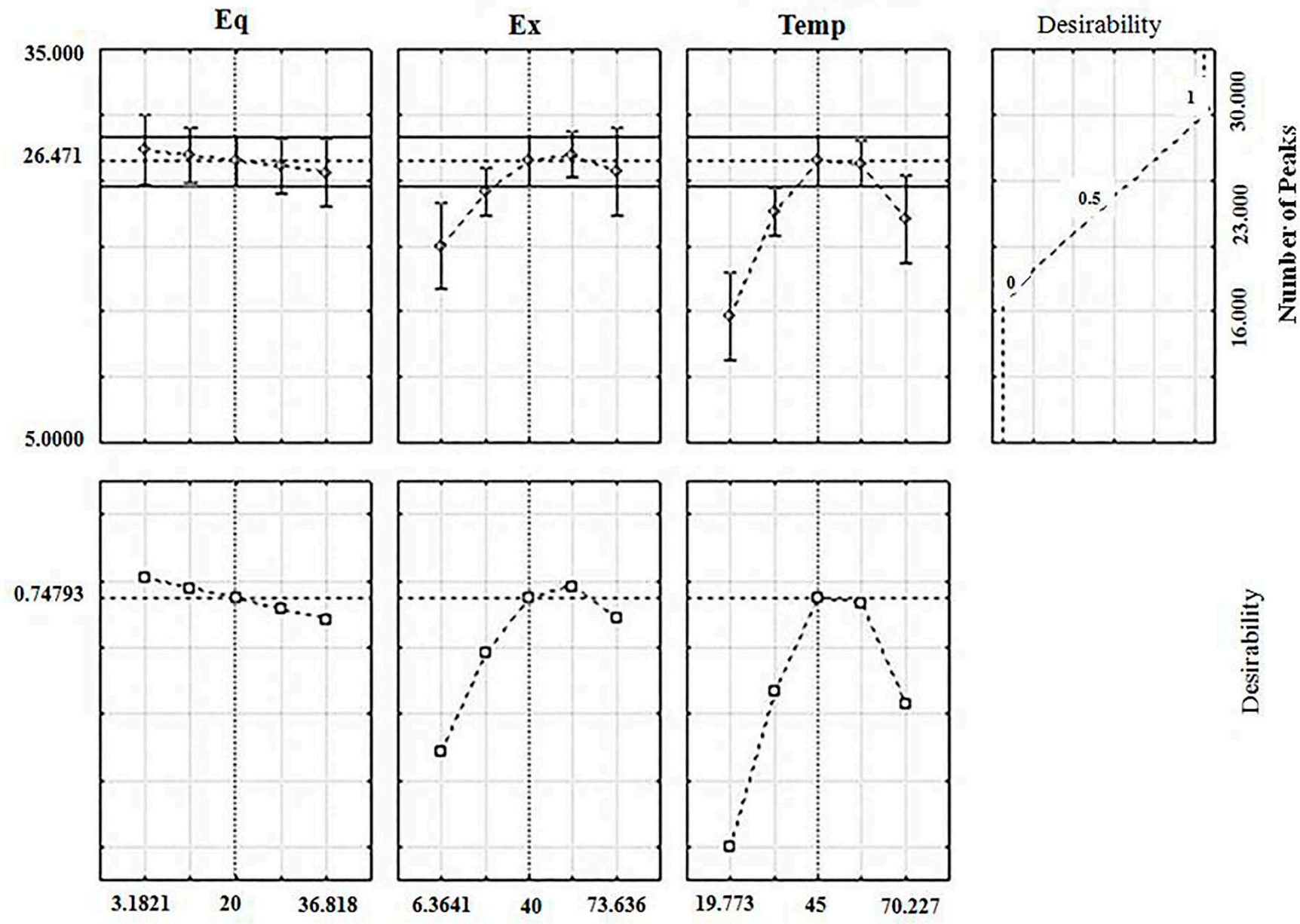

Figure 3. Profile of Predicted Values and Desirability for the number of peaks captured by HS-SPME-GC-MS in Coalho cheese. Eq (Equilibrium Time), Ex (Extraction Time) and Temp (Extraction Temperature).

optimal conditions for cheese extraction are obtained with a temperature of $45{ }^{\circ} \mathrm{C}$ and extraction time of 40 minutes. The desirability values these authors obtained are the same as the ones obtained in this study.

In their research on Gokceada cheese, a traditional type of goat cheese, Hayaloglu et al. (2013) reported that the ideal conditions for volatile compound extraction were obtained at $40{ }^{\circ} \mathrm{C}$ with extraction time of 30 minutes. These conditions differ from those found in this study. Bontinis et al. (2012) also reported a desirability value different from the one obtained in this study; they performed the extraction of volatiles from Xinotyri cheese, a traditional Greek goat cheese, at the temperature of $65^{\circ} \mathrm{C}$, with extraction time of 20 minutes.

\subsection{Model validation}

Applying the desirable value of each dependent variable to the equation of number of peaks (Equation 1), the result obtained was 26 peaks. With the optimal points reproduced in triplicate, the mean of the experimental data was 30 peaks, and the standard deviation was 1 . When submitted to ANOVA and to a t-test $(\mathrm{p}<0.05)$, both predicted and experimental values showed no significant difference. This indicates that the proposed model was adjusted to the experimental data. Besides, the experimental values obtained were all within the $95 \%$ reliability limit.

\subsection{Characterization of the volatile compounds found in caprine Coalho cheese}

A total of 32 volatile compounds were detected after being extracted (through SPME) from caprine Coalho cheese: 5 alcohols, 5 esters, 3 ketone, 6 acids, 3 aldehydes, 3 terpenes and 7 hydrocarbons (Table 2). Among these compounds, the most abundant were decane and hexanoic acid. The latter is responsible for the characteristic smell of goat dairy products.

The alcohol compounds found in cheeses can be formed in a number of metabolic reactions: through fermentation, ketone reduction, aminoacid and fatty acid degradation, all performed by microbiological and biochemical activities (Kaminarides et al., 
2007; Bontinis et al., 2012). Most of these compounds are usually formed during storage, but are quickly dispersed due to their high volatility (Hayaloglu et al., 2013).

The most abundant alcohol compound found in the Coalho cheese was 2-Propanol, 1-methoxy. Delgado et al. (2010) also reported its presence in ovine cheese. The esters detected in the caprine Coalho cheese were ethyl acetate, ethyl butanoate, ethyl hexanoate, ethyl octanoate and ethyl decanoate. According to Bontinis et al. (2012), esters are originated in the esterification reaction between short chain fatty acids and ethanol. Among the esters found in the Coalho cheese ethyl butanoate, ethyl hexanoate and ethyl octanoate were the most common. All three are originated from acids which possess the typical smell of caprine cheese. In their research, Delgado et al. (2011) also found high proportions of these three esters.

Only one ketone was found in the caprine Coalho cheese: 2-heptanone. This compound can be found in other types of cheese and has an herbaceous aroma. It is the product of $\beta$-oxidation of free fatty acids, which are released during lipolysis (Vandeweghe \& Reineccius, 1990; Bontinis et al., 2012). Atasoy et al. (2013) who studied ovine, caprine and mixed Urfa cheese, reported the detection of this compound in both fresh and matured

Table 2. Volatile compounds in the headspace of in caprine Coalho cheese.

\begin{tabular}{|c|c|c|c|c|c|c|c|c|c|}
\hline Number & Compouds & $\mathrm{C}_{1}^{\mathrm{a}}$ & $\mathrm{CV}^{\mathrm{b}}$ & $\mathrm{C}_{2}^{\mathrm{c}}$ & $\mathrm{CV}$ & $\mathrm{C}_{3}{ }^{\mathrm{d}}$ & $\mathrm{CV}$ & $\mathrm{LRI}^{\mathrm{e}}$ & $\mathrm{ID}^{\mathrm{f}}$ \\
\hline \multicolumn{10}{|l|}{ Acohol } \\
\hline 1 & Ethanol & 4.42 & 73 & 3.73 & 20 & 1.13 & 43 & $<600$ & A \\
\hline 3 & 2-Butanol & $\mathrm{ND}^{\mathrm{g}}$ & - & 21.16 & 1 & ND & - & $<600$ & $\mathrm{~A}$ \\
\hline 8 & 3-methyl-1-Butanol & 0.35 & 3 & 3.67 & 12 & 1.07 & 10 & 760 & $\mathrm{~A} / \mathrm{B}$ \\
\hline 11 & 1-Pentanol & ND & - & 0.16 & 104 & 0.55 & 87 & $<600$ & A \\
\hline 26 & 2-methyl-1-Decanol & 1.78 & 18 & ND & - & ND & - & 1160 & $\mathrm{~A} / \mathrm{B}$ \\
\hline \multicolumn{10}{|l|}{ Esters } \\
\hline 4 & Ethyl Acetate & 0.87 & 63 & 1.77 & 99 & 2.01 & 70 & $<600$ & $\mathrm{~A}$ \\
\hline 12 & Ethyl Butanoato & 3.38 & 14 & 8.99 & 1 & 4.82 & 54 & 808 & $\mathrm{~A} / \mathrm{B}$ \\
\hline 19 & Ethyl Hexanoato & 4.48 & 13 & 6.32 & 1 & 10.24 & 8 & 1007 & $\mathrm{~A} / \mathrm{B}$ \\
\hline 28 & Ethyl Octanoato & 5.50 & 6 & 2.11 & 14 & 4.86 & 34 & 1198 & $\mathrm{~A} / \mathrm{B}$ \\
\hline 30 & Ethyl Decanoato & 3.10 & 15 & ND & - & ND & - & 1404 & $\mathrm{~A} / \mathrm{B}$ \\
\hline \multicolumn{10}{|l|}{ Ketones } \\
\hline 2 & 2-pentanone & 3.64 & 18 & 3.4 & 18 & 1.70 & 53 & $<600$ & A \\
\hline 7 & 3-hydroxy-2-Butanone & 3.91 & 99 & 8.73 & 14 & ND & - & 722 & $\mathrm{~A} / \mathrm{B}$ \\
\hline 15 & 2-Heptanone & 2.32 & 7 & 4.2 & 12 & 1.53 & 11 & 899 & $\mathrm{~A} / \mathrm{B}$ \\
\hline \multicolumn{10}{|l|}{ Acids } \\
\hline 5 & Acetic acid & ND & - & 0.89 & 5 & 15.20 & 3 & $<600$ & $\mathrm{~A}$ \\
\hline 13 & Butanoic acid & 2.96 & 10 & 4.02 & 32 & 3.10 & 20 & 823 & $\mathrm{~A} / \mathrm{B}$ \\
\hline 14 & Pentanoic acid & ND & - & 3.09 & 6 & 0.73 & 23 & 880 & $\mathrm{~A} / \mathrm{B}$ \\
\hline 20 & Hexanoic acid & 16.00 & 20 & 7.60 & 71 & 13.76 & 60 & 1016 & $\mathrm{~A} / \mathrm{B}$ \\
\hline 27 & Octanoic acid & 1.47 & 50 & 0.02 & 2 & 4.17 & 34 & 1198 & $\mathrm{~A} / \mathrm{B}$ \\
\hline 29 & Decanoic acid & 0.27 & 3 & ND & - & ND & - & 1401 & $\mathrm{~A} / \mathrm{B}$ \\
\hline \multicolumn{10}{|l|}{ Aldehydes } \\
\hline 6 & 3-methylbutanal & 0.61 & 54 & 0.95 & 38 & 0.26 & 7 & $<600$ & $\mathrm{~A}$ \\
\hline 17 & Benzaldehyde & 5.86 & 117 & ND & - & ND & - & 986 & $\mathrm{~A} / \mathrm{B}$ \\
\hline 21 & 2-octenal & ND & - & ND & - & 1.85 & 45 & 1033 & $\mathrm{~A} / \mathrm{B}$ \\
\hline \multicolumn{10}{|l|}{ Terpenes } \\
\hline 16 & a-Pinene & 2.21 & 3 & 5.51 & 19 & 5.11 & 3 & 945 & $\mathrm{~A} / \mathrm{B}$ \\
\hline 31 & Copaene & 0.83 & 141 & 1.32 & 14 & 2.56 & 65 & 1406 & $\mathrm{~A} / \mathrm{B}$ \\
\hline 32 & Caryophyllene & 2.95 & 141 & 6.64 & 11 & 7.50 & 8 & 1460 & $\mathrm{~A} / \mathrm{B}$ \\
\hline \multicolumn{10}{|l|}{ Hydrocarbons } \\
\hline 9 & 3-ethyl-2-methyl Pentane & 0.29 & 73 & 0.12 & 39 & 0.91 & 67 & 765 & $\mathrm{~A} / \mathrm{B}$ \\
\hline 10 & Tolueno & 0.18 & 21 & 0.66 & 33 & 0.59 & 30 & 789 & $\mathrm{~A} / \mathrm{B}$ \\
\hline 18 & Decane & 14.14 & 8 & 1.38 & 10 & 5.60 & 1 & 1003 & $\mathrm{~A} / \mathrm{B}$ \\
\hline 22 & 3-methyldecane & 1.15 & 5 & ND & - & 1.78 & 7 & 1059 & $\mathrm{~A} / \mathrm{B}$ \\
\hline 23 & 4-methyl-1-Decene & 2.10 & 2 & ND & - & ND & - & 1069 & $\mathrm{~A} / \mathrm{B}$ \\
\hline 24 & Undecane & 9.16 & 0 & 3.56 & 9 & 8.97 & 11 & 1104 & $\mathrm{~A} / \mathrm{B}$ \\
\hline 25 & 4-methydecane & 5.02 & 23 & ND & - & ND & - & 1118 & $\mathrm{~A} / \mathrm{B}$ \\
\hline
\end{tabular}

${ }^{a}$ Artisinal caprine cheese. ${ }^{b} \% \mathrm{CV}$, percentage of coefficient of variation. ${ }^{\mathrm{c}}$ caprine cheese $-1 .{ }^{\mathrm{d}}$ caprine cheese $-2 .{ }^{\mathrm{e}}$ Linear retention indices. ${ }^{\mathrm{f}} \mathrm{A}$, mass spectrum and LRI agree with those of an authentic compound ran on VF-5ms column. B, mass spectrum agrees with reference spectrum in the NIST/EPA/NIH mass spectral database and LRI agree with those in the literature (Adams, 2007; Madruga et al., 2013; Mottram, 2014). ${ }^{\mathrm{g}}$ ND, not detected. 
samples. Hayaloglu et al. (2013) also found 2-heptanone in caprine Gokceada cheese.

Acids are compounds that can be formed through lipolysis, proteolysis and lactose fermentation. It is the presence of acids such as hexanoic acid, octanoic acid and decanoic acid that gives goat dairy products their distinctive smell. These three acids are also known as caproic acid, caprylic acid and capric acid respectively (Bontinis et al., 2012; Hayaloglu et al., 2013). The acids found in caprine Coalho cheese were butanoic acid, hexanoic acid, octanoic acid and decanoic acid; hexanoic acid was the most abundant of these four. Butanoic acid is known in literature for its rancid, unpleasant smell, and its presence in cheese samples is therefore undesirable (Delgado et al., 2011). The aldehydes found in the Coalho cheese were 3-methylbutanal, heptanal and benzaldehyde, the last being the most abundant. Benzaldehyde has a typical almond-like aroma and was also detected in cheeses by various authors in their research (Delgado et al., 2010; Wolf et al., 2010). Aldehydes are known as transitory volatile compounds, because they are quickly converted into acids or alcohols. Some are formed through the Strecker reaction, such as 2-methylbutanal (Atasoy et al., 2013; Kondyli et al., 2013).

Three types of terpene were detected in the Coalho cheese: a-pinene, copaene and caryophyllene. According to Wolf et al. (2010), terpenes are compounds produced by plants and therefore, their presence in milk or in dairy products is due to whatever vegetables the animal has eaten. This way, the presence of these compounds may help in determining the geographical origin of the cheese. The other aromatic compounds found in the caprine Coalho cheese were 10 hydrocarbons, of which decane was the most common.

\section{Conclusions}

The optimal conditions for SPME extraction of volatile compounds from caprine Coalho cheese were obtained with equilibrium time of 20 minutes, extraction time of 40 minutes, and extraction temperature of $45^{\circ} \mathrm{C}$. Optimization was confirmed by the desirability parameter, which attained a value considered good and acceptable by literature. Therefore, the model obtained was validated. In the optimal conditions, 32 volatile compounds from caprine Coalho cheese were detected.

\section{References}

Adams, R. P. (2007). Identification of essential oils components by gas chromatography mass spectroscopy (4th ed, 804 p.). Illinois: Allured Publishing Corporation.

Akhanazarova, S., \& Kafarov, V. (1982). Experiment optimization in chemistry and chemical engineering. Moscow: Mir Publishers.

Atasoy, A. F., Hayaloglu, A. A., Kirmaci, H., Levent, O., \& Türkoğlu, H. (2013). Effects of partial substitution of caprine for ovine milk on the volatile compounds of fresh and mature Urfa cheeses. Small Ruminant Research, 115(3), 113-123. http://dx.doi.org/10.1016/j. smallrumres.2013.09.002.

Barros, E. P., Moreira, N., Pereira, G. E., Leite, S. G. F., Rezende, C. M., \& Pinho, P. G. (2012). Development and validation of automatic HS-SPME with a gas chromatography-ion trap/mass spectrometry method for analysis of volatiles in wines. Talanta, 101, 177-186. http://dx.doi.org/10.1016/j.talanta.2012.08.028. PMid:23158309.

Bontinis, T. G., Mallatou, H., Pappa, E. C., Massouras, T., \& Alichanidis, E. (2012). Study of proteolysis, lipolysis and volatile profile of a traditional Greekgoat cheese (Xinotyri) during ripening. Small Ruminant Research, 105(1-3), 193-201. http://dx.doi.org/10.1016/j. smallrumres.2012.01.003.

Condurso, C., Verzera, A., Romeo, V., Ziino, M., \& Conte, F. (2008). Solid-phase microextraction and gas chromatography mass spectrometry analysis of dairy product volatiles for the determination of shelf-life. International Dairy Journal, 18(8), 819-825. http:// dx.doi.org/10.1016/j.idairyj.2007.12.005.

Delgado, F. J., González-Crespo, J., Cava, R., \& Ramírez, R. (2011). Formation of the aroma of a raw goat milk cheese during maturation analysed by SPME-GC-MS. Food Chemistry, 1156(3), 1153-1163. http://dx.doi.org/10.1016/j.foodchem.2011.05.096. PMid:25212351.

Delgado, F. J., González-Crespo, J., Cava, R., García-Parra, J., \& Ramírez, R. (2010). Characterisation by SPME-GC-MS of the volatile profile of a Spanish soft cheese P.D.O. Torta del Casar during ripening. Food Chemistry, 118(1), 182-189. http://dx.doi.org/10.1016/j. foodchem.2009.04.081.

González-Martín, I., Hernández-Hierro, J. M., González-Pérez, C., Revilla, I., Vivar-Quintana, A., \& Lobos Ortega, I. (2014). Potential of near infrared spectroscopy for the analysis of volatile components in cheeses. LWT - Food Science and Technology (Campinas.), 55(2), 666-673.

Hayaloglu, A. A., Yasar, K., Tolu, C., \& Sahingil, D. (2013). Characterizing volatile compounds and proteolysis in Gokceada artisanal goat cheese. Small Ruminant Research, 113(1), 187-194. http://dx.doi. org/10.1016/j.smallrumres.2013.01.001.

Januszkiewicz, J., Sabik, H., Azarnia, S., \& Lee, B. (2008). Optimization of headspace solid-phase microextraction for the analysis of specific flavors in enzyme modified and natural Cheddar cheese using factorial design and response surface methodology. Journal of Chromatography A, 1195(1-2), 16-24. http://dx.doi.org/10.1016/j. chroma.2008.04.067. PMid:18495140.

Kaminarides, S., Stamou, P., \& Massouras, T. (2007). Changes of organic acids, volatile aroma compounds and sensory characteristics of Halloumi cheese kept in brine. Food Chemistry, 100(1), 219-225. http://dx.doi.org/10.1016/j.foodchem.2005.09.039. PMid:26054284.

Kondyli, E., Massouras, T., Katsiari, M. C., \& Voutsinas, L. P. (2013). Lipolysis and volatile compounds of Galotyri-type cheese made using different procedures. Small Ruminant Research, 113(2-3), 432-436.

Ma, Q. L., Hamid, N., Bekhit, A. E. D., Robertson, J., \& Law, T. F. (2013). Optimization of headspace solid phase microextraction (HS-SPME) for gas chromatography mass spectrometry (GC-MS) analysis of aroma compounds in cooked beef using response surface methodology. Microchemical Journal, 111, 16-24. http://dx.doi. org/10.1016/j.microc.2012.10.007.

Madruga, M. S., Guerra, I. C. D., Queiroz, A. L. M., Brasil, L. M. S., \& Ishihara, Y. M. (2013). A Volatiles and water- and fat-soluble precursors of Saanen goat and cross suffolk lamb flavour. Molecules (Basel, Switzerland), 18(2), 2150-2165. http://dx.doi.org/10.3390/ molecules18022150. PMid:23434868.

Mallia, S., Fernández-García, E., \& Bosset, J. (2005). Comparison of purge and trap and solid phase microextraction techniques for studying the volatile aroma compounds of three European PDO hard cheeses. International Dairy Journal, 15(6-9), 741-758. http:// dx.doi.org/10.1016/j.idairyj.2004.11.007. 
Moio, L., \& Addeo, F. (1998). Grana Padano cheese aroma. The Journal of Dairy Research, 65(2), 317-333. http://dx.doi.org/10.1017/ S0022029997002768.

Mottram, R. (2014). LRI \& Odour Database. London: Flavour Research Group/School of Food Biosciences/University of Reading. Retrieved from http://www.odour.org.uk.html

Oliveira, E. M. G., Garcia, E. F., Queiroga, R. C. R. E., \& Souza, E. L. (2012). Technological, physicochemical and sensory characteristics of a Brazilian semi-hard goat cheese (coalho) with added probiotic lactic acid bacteria. Scientia Agricola, 69(6), 370-379. http://dx.doi. org/10.1590/S0103-90162012000600005.

Pérez-Palacios, T., Petisca, C., Melo, A., \& Ferreira, I. M. P. L. V. O. (2012). Quantification of furanic compounds in coated deep-fried products simulating normal preparation and consumption: optimisation of HS-SPME analytical. Food Chemistry, 135(3), 1337-1343.

Pinho, O., Pérès, C., \& Ferreira, I. M. (2003). Solid-phase microextraction of volatile compounds in "Terrincho"ewe cheese. Comparison of different fibers. Journal of Chromatography A, 1011(1-2), 1-9. http://dx.doi.org/10.1016/S0021-9673(03)01066-5. PMid:14518757.

Queiroga, R. C. R. E., Santos, B. M., Gomes, A. M. P., Monteiro, M. J., Teixeira, S. M., Souza, E. L., Pereira, C. J. D., \& Pintado, M. M. E. (2013). Nutritional, textural and sensory properties of Coalho cheese made of goats', cows' milk and their mixture. LWT -. Food Science and Technology (Campinas.), 50(2), 538-544.

Santos, K. M. O., Bomfim, M. A. D., Vieira, A. D. S., Benevides, S. D., Saad, S. M. I., Buriti, F. C. A., \& Egito, A. S. (2012). Probiotic caprine Coalho cheese naturally enriched in conjugated linoleic acids a vehicle for Lactobacillus acidophilus and beneficial fatty acids. International Dairy Journal, 24(2), 107-112. http://dx.doi. org/10.1016/j.idairyj.2011.12.001.

Silva, R. A., Lima, M. S. F., Viana, J. B. M., Bezerra, V. S., Pimentel, M. C. B., Porto, A. L. F., Cavalcanti, M. T. H., \& Lima, J. L. Fo. (2012). Can artisanal "Coalho" cheese from Northeastern Brazil be used as a functional food? Food Chemistry, 135(3), 1533-1538. http://dx.doi. org/10.1016/j.foodchem.2012.06.058. PMid:22953890.

Statsoft, Inc. (2007). Statistica (data analysis software system), version 8.0. Tulsa: STATSOFT.

Trujillo-Rodríguez, M. J., Yu, H., Cole, W. T. S., Ho, T. D., Pino, V., Anderson, J. L., \& Afonso, A. N. (2014). Polymeric ionic liquid coatings versus comercial solid-phase microextraction coatings for the determination of volatile compounds in cheeses. Talanta, 121, 153-162. http://dx.doi.org/10.1016/j.talanta.2013.12.046. PMid:24607122.

Vandeweghe, P., \& Reineccius, G. A. (1990). Comparison of flavor isolation techniques applied to Cheddar cheese. Journal of Agricultural and Food Chemistry, 38(7), 1549-1552. http://dx.doi.org/10.1021/ jf00097a026.

Wolf, I. V., Perotti, M. C., Bernal, S. M., \& Zalazar, C. A. (2010). Study of the chemical composition, proteolysis, lipolysis and volatilecompounds profile of commercial Reggianito Argentino cheese: Characterization of Reggianito Argentino cheese. Food Research International, 43(4), 1204-1211. http://dx.doi.org/10.1016/j.foodres.2010.02.018. 